\title{
The Dynamics of Party Organizational Development*
}

Paul S. Herrnson, University of Maryland

David Menefee-Libey, Pomona College

Once characterized as poor, transitory, and "powerless," national party organizations in the United States are now financially secure, stable, and highly influential in election campaigns and in their relations with state and local party committees. The transformation of the Democratic and Republican national, congressional, and senatorial campaign committees can be explained using theories of organizational change from the organizational behavior literature and traditional arguments about electoral competition and coalition-building from the parties literature. This paper explains the timing and content of party organizational development by focusing on the nature of the problems that confront the parties, the crises that create opportunities for party organizational change, the motives and behaviors of political entrepreneurs instigating the change, and the internal politics of the party organizations themselves. The explanation accounts for the different paths of institutionalization taken by the six national party organizations and for the variations in the roles they currently play in the electoral process.

For decades political scientists have debated whether American political parties are in decline or resurgence. The debates over the party-inthe-electorate and the party-in-government continue, but most observers agree that party organizations are alive and well. The national organizations of both major parties are now larger and more adept at political campaigning and more involved in party-building than ever (Cotter and Bibby 1980; Conway 1983; Adamany 1984; Kayden and Mahe 1985; Sabato 1988). They have adapted to the technologically sophisticated, capital intensive, candidate-centered nature of contemporary elections by becoming major suppliers, vendors, and brokers of campaign money and services (Herrnson 1988; Frantzich 1989). The Democratic National Committee (DNC) also has become an important regulator of state and local party activities, especially in the selection of presidential convention delegates (Ranney 1975; Shafer 1983; Wekkin 1984). National party organizations, it is widely agreed, have fundamentally changed over the past 20 years. They have been transformed from weak, powerless agencies capable of providing only minimal intraparty coordination (Cotter and Hennessy 1964) to highly effective political campaigners and powerful governors of intraparty affairs.

These developments address many questions about party organizational decline versus resurgence, but they raise a whole new set of questions about the process of party development. Why have the national party organizations changed so dramatically? Are they responding to internal

*We wish to thank M. Margaret Conway, Kathleen Dolan, Leon Epstein, Jerome Mileur, Mark Rom, Thomas Weko, Joseph White, and Gary Wekkin and Donald Whistler, the editors of the Journal, for their helpful comments and suggestions. 
political dynamics, to upheaval in their environment, or both? Why did the Republican national party organizations adapt more quickly to the new style of campaign politics than their Democratic counterparts? Why have the Democratic and Republican congressional campaign committees become more highly developed centers of campaign services than the parties' national and senatorial campaign committees? Why has the DNC become a more important agency of intraparty regulation than its Republican counterpart?

Joseph Schlesinger (1985) offers a plausible explanation, suggesting that the resurgence of the political parties has been a functional response to electoral dealignment, more open nominating processes, the separation of presidential from congressional elections, and the growth of party competition nationwide. He argues that insecurities caused by the increased competitiveness of elections have led to the emergence of party organizations as providers of important campaign services. This is, at best, a partial explanation for the recent developments in party politics. Environmental change is not a wholly sufficient explanation for party transformation. Schlesinger's answer does not adequately explain a number of factors, including why such a long delay preceded the parties' revitalization, why the Republican Party was the first to develop extensive campaign services when the Democratic Party was suffering greater electoral decline, why the Democratic Party far exceeded the Republicans in the adoption of national party rules reform, and why important differences have emerged in the structures and missions of the six national party organizations. A functional account cannot explain the timing and variety of current organizational development.

Leon Epstein (1986) offers a more detailed account of party development, suggesting that the Democrats pursued a path of centralized rule making in response to the party's reform movement of 1968 through 1974 , while the Republicans developed strong national organizations in order to regain lost competitiveness after the Watergate disaster. He identifies the increased power of national party organizations to be an important departure from past experience, but at the same time calls attention to the limits of this change. The separation of powers, federalism, state-regulated primary nominations, and a political culture that is ambivalent towards parties combine to prevent American parties from becoming as highly centralized, programmatic, or powerful as parties in other western democracies.

While Epstein and Schlesinger contribute to our understanding of party development, their explanations leave us without answers to some 
important questions: What factors instigate changes as fundamental as those that have transformed the party committees in Washington, D.C.? And, why does a party committee follow one path of organizational development instead of another, and at one time rather than another? This article addresses these questions by exploring both the internal and external dynamics that shape the timing and content of party organizational change, and by demonstrating the central role that political entrepreneurs play in advancing a party's organizational development. Traditional arguments about the importance of electoral competition and coalition-building from the parties literature are combined with arguments about organizational change from the organizational behavior literature to produce a fuller, more consistent account of the development of American national party organizations during the last two decades.

\section{Crisis, Entrepreneurship, and National Party Institutionalization}

Party organizations in the United States exist primarily to perform one essential task: to help their candidates run for public office. National party organizations historically have been highly transient, swelling during presidential election years and virtually disappearing after election day (Cotter and Hennessy 1964). They also have been less directly involved in subpresidential campaigns than their counterparts at the state and local levels. Instead, national parties have worked toward their goals indirectly, by helping lower level party organizations, and by holding conventions, commissions, caucuses, and other arenas for bargaining, coalition-building, and decisionmaking (see e.g., Eldersveld 1982). They also have enforced rules, carried out mandates, coordinated campaign events, and helped to set national political agendas.

Recently, however, national parties have become institutionalized; they are fiscally solvent and have organizational stability, large diversified staffs, and professional-bureaucratic operating procedures (see Cotter and Bibby 1980; Kayden 1980; Herrnson, 1988). Equally important, they are assuming a more significant role in election campaigns. Much of this change has been shaped by the changing needs of candidates, by pressures exerted by factions within the parties, and by transformations in the broader political environment. Although developments that are exogenous to the party committees can create the need for organizational change, they are not sufficient conditions for organizational change to be introduced, nor are they capable of determining the specific content of the change that actually occurs. Endogenous pressures placed on the organizations by 
those who work in them are also important to understanding the dynamics of party organizational change.

The patterns of change occurring in American parties are not unique to party organizations. They follow a path similar to those observed in other areas of politics, resembling patterns described in Robert Salisbury's (1969) exchange theory of interest groups, in James Q. Wilson's (1973) arguments about political organizations, in Hugh Heclo's (1974) and John Kingdon's (1984) discussions of policy formation, in Thomas Cronin's (1975) explanation for the growth of the White House staff, and in Paul Light's (1985) analysis of the expansion of the Office of the Vice President. Salisbury and Kingdon have observed that dramatic changes in organizations or public policies usually occur when a crisis or some other destabilizing event provides an opportunity for a policy entrepreneur to initiate change. Kingdon defines policy entrepreneurs as "advocates who are willing to invest their resources - time, energy, reputations, moneyto promote a position in return for anticipated future gain in the form of material, purposive, or solidary benefits" (188). Political (or party) entrepreneurs have similar motives, but their efforts are directed toward changing a political organization rather than altering public policy. Both types of entrepreneurs derive their influence from their substantive expertise, occupation of an authoritative decision-making position, or ability to speak for one or more people in such positions. Both types of entrepreneurs also possess negotiating skills and are persistent in the pursuit of their goals.

The process of party organizational change can be summarized in roughly five steps: 1) a critical event or crisis disturbs the status quo, opening a window of opportunity for change; 2) a search for a solution takes place; 3 ) a variety of people, who are not necessarily formal group leaders or members, pose alternative solutions to the problem; 4) political entrepreneurs select from the proposed solutions and work to resolve the problem and advance their own careers or interests; and 5) organizational change and the development of a new status quo follows the adoption of a solution. This scheme differs from other, especially functionalist, theories of change because it points to two conditions that are necessary for organizational change and that help to shape the timing and content of that change: heightened environmental pressures caused by a crisis, and political entrepreneurs who respond to the crisis.

This study focuses on national party organizations in the United States and the roles that entrepreneurial chairmen played in transforming them. However, the framework used here is broad enough to apply to state and local party committees and party organizations in other countries. 
Moreover, it can be used to examine the roles that entrepreneurial party staff, many of whom possess motives and behaviors similar to those of party committee chairs, play in transforming party organizations. ${ }^{1}$

\section{Organizational Response to a Factional Crisis: \\ The Democratic National Committee and National Convention}

The Democratic Party's reform politics since 1968 are usually considered alone, outside of the broader spectrum of party organizational development. Despite their unique and dramatic elements, Democratic reform politics fit well into the scheme discussed here. The timing and content of party organizational change from 1968 through 1974 depended heavily on the opportunities brought on by crisis and the energies of political entrepreneurs. At a time of unmatched public attention to party affairs and unmatched potential rewards for politicians, a number of nowfamiliar Democratic entrepreneurs stepped forward to initiate the process of organizational change.

The catalyst to the process was the divisive presidential nomination fight between Senator Eugene McCarthy of Minnesota, Senator Robert Kennedy of New York, and Vice President Hubert Humphrey. After Kennedy's assassination in June, when it became clear that Humphrey would win the nomination without entering a single primary, protesters targeted the national convention in Chicago. Deep factional divisions opened within the party. The "party regulars" who controlled the convention were challenged by a volatile reformist coalition of "new-politics liberals," who opposed the Vietnam war and the Johnson-Humphrey administration, and supported civil rights, feminism, the youth vote, environmentalism, and a broad array of activist causes. The reform faction used protests to press party regulars, who held formal control of the convention and the DNC, for organizational change. The convention mandated an official party commission to study the matter in what then was considered a minor vote in the midst of the chaotic Chicago convention (Shafer 1983). The issue was set aside until January 1969, after Humphrey narrowly lost the election and his DNC chair Lawrence O'Brien had stepped down. The new chair, Senator Fred Harris of Oklahoma, appointed a Commission on Party Structure and Delegate Selection, to be chaired by Senator George McGovern of South Dakota. McGovern and his staff invested tremendous energy into advancing the mandate of the small, poorly financed commission. By the end of 1969 , they had convened 17 regional hearings, captured the public spotlight and 
the support of reformist liberals, and developed a report, "Mandate for Reform," that recommended sweeping changes in Democratic Party politics. ${ }^{2}$ The report's most dramatic provisions called for state parties to open delegate contests to easier public participation, to allocate delegates in proportion to voter support for candidates, and to take "affirmative action" to assure the participation of racial minorities, women, and young people in nomination politics (Commission on Party Structure and Delegate Selection 1969). McGovern pressed the commission's vague mandate to the limit by sending "compliance letters" to all state Democratic chairs, outlining the commission's guidelines and instructing them to comply under the threat of delegation challenges at the 1972 convention.

By mid-1971, after McGovern had left the commission to run for president and Representative Donald Fraser of Minnesota had moved from member to chair of the commission, it became clear that the commission alone could not implement its reform agenda over the objections of the state chairs. O'Brien, who had returned to the chairmanship of the DNC, convinced committee members to shift compliance responsibilities to the national committee's staff in order to placate reform advocates and carry out what he called "the greatest goddamn change since the advent of the two-party system" (Glass and Cottin 1971, 1293). Thus, after a period of aggressive entrepreneurism by McGovern and Fraser, and sustained pressure from reform activists, the first stage of reforms was institutionalized within the DNC. The national committee had become the ultimate agency of intraparty regulation, amassing the power to enforce state party compliance with national party rules.

The 1972 Democratic National Convention could not match 1968 for drama, but it continued the factional crisis on different terms with nearly endless battles over delegate credentials and the implementation of the McGovern-Fraser Commission reforms. Before it was over, McGovern had won the presidential nomination and reform activists gained the convention's mandate for a second stage of reform: the writing of a formal party charter. They hoped the charter would further institutionalize the reforms, placing them beyond dispute. The resolutions mandated both the creation of yet another commission to develop a draft charter and a midterm party conference in 1974 to pass the final version.

The Charter Commission's history was in many ways similar to that of the McGovern-Fraser Commission. Its membership was appointed by McGovern's DNC chair Jean Westwood and her successor, Robert Strauss. Strauss' appointee to chair the Charter Commission, former North Carolina Governor Terry Sanford, developed a draft charter that was 
consistent with most of the goals of the McGovern-Fraser Commission, but less extreme than proposals offered by Fraser in 1972. As they had with the earlier commission, party regulars abstained from most of the meetings out of concern that the Sanford commission's report would still be too reformist. After factional squabbles threatened to derail the process when the report was published in August 1974, Strauss lined up enough support among party regulars to convince Democratic governors to endorse a moderately reformist charter in November (Malbin 1974b; Goodwin 1974).

At the Democratic Midterm Conference in December, Strauss worked feverishly to establish a consensus behind the governors' recommendations, and the charter was endorsed by wide margins. Despite the apparent lack of drama at the meeting, its results were very significant for the Democratic Party. The new charter institutionalized the Compliance Review Commission's oversight of state delegate selection procedures and tripled the size of the DNC to make room for proportional representation of delegates representing women, young people, and racial minorities. ${ }^{3}$ In short, the charter reoriented the DNC by requiring that a substantial share of its financial and staff resources support rules reform and reformist activities in the future (Walters 1974; Democratic National Committee n.d.). In subsequent years, Democratic conventions and the DNC have repeatedly mandated commissions to tinker with various aspects of the rules; however, the core reform achievements have never been seriously challenged.

The events of 1968 through 1974 show the importance of crisis, entrepreneurism, and intraparty politics in shaping the direction of party organization development. The Democratic Party was thrown into crisis by factional conflict between pro-Humphrey regulars and "new-politics liberals," who focused their attacks on the party's presidential nominating procedures. A series of ambitious political entrepreneurs, most notably George McGovern, Donald Fraser, Terry Sanford, and Robert Strauss, led commissions that transformed the DNC and Democratic National Conventions into rule-making and rule-enforcement bodies having the authority to regulate state party activity. At the same time, the reformers tried to advance their own careers: McGovern rewrote the rules so they would help him win the Democratic nomination in 1972; Fraser worked to advance his standing as a liberal leader in the House; Sanford sought to establish a base from which to pursue federal office, running for the presidency and eventually winning a seat in the U.S. Senate; and the Texan Strauss sought to advance his standing within the Washington establishment, and was 
rewarded with cabinet-level status as Special Trade Representative in the Executive Office of the President under Jimmy Carter.

\section{Organizational Response to a Crisis of Competition}

In contrast to the factional crisis that set the stage for the transformation of the DNC and Democratic National Conventions after 1968, the catalysts for Republican and Democratic national party organizational development in the mid-1970s and 1980s were crises of competition. The Republican crisis centered on the negative impact that the Watergate scandal had on party success in the mid-1970s. The Democratic crisis revolved around that party's poor performance, including loss of the Senate and the Presidency, in the 1980 elections.

\section{The Republican National Committee}

Watergate reversed the tentative rebirth of Republican competitiveness that had taken place following the Republicans' electoral fiasco in the 1964 elections. ${ }^{4}$ The scandal badly tarnished the party's image and cut into its level of public support. Beginning in 1974, a growing number of the party's candidates experienced major defeats. The Republicans lost 49 seats in the House that year, had an incumbent president defeated two years later, and by 1977 controlled only 12 governorships and four state legislatures.

The Republicans' crisis of competition created an opportunity for organizational change at the Republican National Committee (RNC). After the 1974 election, party leaders debated intensely over what route the party should follow to recapture lost competitiveness. One group of leaders suggested attempting to broaden the party's base by implementing participatory reforms similar to those adopted by the Democratic Party after the 1968 election. Another group of leaders preferred to concentrate on party-building programs similar to those introduced by Ray Bliss after Goldwater's defeat in 1964 (Malbin 1975; Cotter and Bibby 1980; Bibby 1981).

Once Mary Louise Smith announced her resignation as RNC chair in November 1976, the politics of organizational development became entwined with the politics surrounding the race for the chairmanship. William Brock campaigned for the position by presenting himself as a conservative capable of rising above factional disputes and by advocating a program of party organizational development. Using these appeals, Brock 
was able to defeat Richard Richards, the preferred choice of presidential candidate Ronald Reagan and the party's conservative wing, and James Baker, the choice of President Ford and party moderates (Malbin 1977; National Journal 1977).

Brock represents an ideal-type political entrepreneur. Defeated in his bid for reelection to the Senate in 1976, Brock found himself out of federal office and without a base of operations in Washington for the first time in 14 years. The RNC chairmanship offered him a new power base and an opportunity to make use of his organizational and fundraising talents. Brock vigorously pursued the position. Once he had won it, he focused his energy on strengthening the national committee, recognizing that by increasing its power and stature he was simultaneously enhancing his own influence and reputation.

Party-building was not a completely new phenomenon prior to Brock's arrival. Nevertheless, his program of party-building differed from those of earlier RNC chairs in some important ways. First, the scale of national party activity conducted under Brock was unrivaled by previous programs. Second, Brock's party-building program had a much more national-level focus than those of his predecessors. Bliss and other Republican "party-building chairs" placed heavy emphasis on using RNC resources to strengthen state and local party organizations. Brock, however, used substantial party resources to strengthen the national committee, thereby increasing its presence in Washington and in states and localities (Cotter and Bibby 1980; Bibby 1981). Whereas Bliss believed that party "strength emanates really from the bottom, [and] all the people at the national level can do is instill a general direction and instill enthusiasm," and Smith saw "parties as growing from the bottom up or the center out, not from the top down" (Malbin 1975, 331), Brock envisioned the national committee as a major source of strength and growth which could be used to develop the rest of the party's organizational apparatus (see e.g., Malbin 1977).

At the national level, Brock made major contributions to the organizational development of the RNC. Committee receipts grew from slightly over $\$ 29$ million in 1976, just before Brock took the helm of the committee, to nearly $\$ 78$ million at the end of his term in 1980 . He expanded the RNC's fledgling direct-mail fundraising program from 350,000 to 1.2 million contributors, giving the committee a broad base of donors whose contributions averaged under $\$ 30$. Support from large contributors and political action committees (PACs) also grew as old programs were enlarged and new programs established. 
Under Brock, the RNC experienced unprecedented organizational growth, permanence, and diversification. It moved into a large headquarters building located a few blocks from the U.S. Capitol and increased its staff from 200 to 350 full-time employees. Professional consultants were hired to raise money, recruit candidates, distribute campaign services, and carry out other election activities.

Brock's state party-building program was equally comprehensive. The RNC assisted state party leaders with modernizing their organizations, developing fundraising programs, and establishing realistic election goals and strategies. State parties also were given access to RNC computers for accounting, data analysis, and the preparation of mailing lists (Bibby 1981; Conway 1983; Price 1984). As Wekkin (1985) and Epstein (1986) point out, the RNC's ability to provide or withhold money, organizational assistance, and election services is similar to the federal government's grants-in-aid system and resulted in an increase in the committee's influence with state and local party organizations.

Finally, Brock initiated an extensive program of campaign activity and support. In 1978 , the RNC contributed $\$ 530,000$ to gubernatorial candidates and $\$ 1.7$ million to 775 contenders for state legislatures (Bibby 1979; Conway 1983). A Local Elections Campaign Division carried out district analyses, candidate recruitment, candidate training and campaign management seminars, and furnished candidates with direct on-site assistance (Bibby 1981). In 1980, the RNC distributed $\$ 6.2$ million in cash and in-kind contributions to candidates for the House, Senate, governorships, and state legislatures. It gave the Reagan-Bush campaign $\$ 4.6$ million, the maximum legal contribution allowed under the Federal Election Campaign Act (Malbin and Skladony 1984). The committee also took primary responsibility for airing television commercials aimed at persuading citizens to "Vote Republican. For a Change" and for coordinating a major voter mobilization program that is believed to have involved as many as one million grassroots activists (Adamany 1984; Price 1984).

Brock's tenure at the RNC represents a major turning point for the committee and for the Republican Party in general. Under his guidance the RNC achieved unprecedented growth and influence both in intraparty politics and election campaigns. New committee programs and activities provided RNC chairs, including Brock, with a source of authority to expand the mandate they received from the president or party leaders who appointed them. Brock's party-building program and skillful distribution of resources made him immensely popular with state and local party officials and enabled him to retain his position during the 1980 presiden- 
tial election, despite heavy pressure from Reagan supporters for Brock's replacement and the established practice of replacing national committee chairs with one of the nominee's supporters (Adamany 1984). Brock was not removed until after the election, when he was rewarded with a Cabinet post in the Reagan administration.

Brock set the RNC on a new path of development, one that would be followed by future RNC chairs and other party organizations well into the 1980s. His stewardship of the RNC was instrumental to the committee becoming a major force in electoral politics. It also earned Brock a reputation as an innovative Republican leader and contributed to his continuing career in national politics. For these reasons, Brock is regarded as an ideal-type political entrepreneur and the principal architect of the modern American party organization.

\section{The National Republican Congressional Committee}

The events that opened a window for organizational change at the RNC created similar possibilities for the National Republican Congressional Committee (NRCC). Following the party's devastating losses in 1974, the Republicans controlled only one-third of all House seats. Republican leaders, including House Minority Leader John Rhodes, believed that further losses would prevent their party from voicing effective opposition (Malbin 1974a). Representative Guy Vander Jagt of Michigan was selected to chair the NRCC following the 1974 election. He took the helm of the committee at a time when Republican leaders were willing to support innovations aimed at increasing the size of the party's House membership and reviving its electoral fortunes more generally. Vander Jagt's motives for vigorously pursuing the NRCC chairmanship centered around a desire to develop a base of political power and make something meaningful out of a lackluster House career. Vander Jagt had spent his early years in the House frequently moving around the committee system, devoting little time to committee work, and showing little interest in the legislative process (Ehrenhalt 1985). For Vander Jagt, the NRCC chairmanship represented an opportunity to exhibit his talents as a fundraiser, organizer, and public speaker, and a chance to establish himself as an important House member and party leader.

After becoming NRCC chair, Vander Jagt devoted himself almost entirely to strengthening the committee, continuing to virtually ignore his regular committee assignments, including the Ways and Means Committee (Ehrenhalt 1985). His efforts had a major impact on the NRCC. When 
he first became chair, the committee had only six full-time staff, an RNCsubsidized budget of less than $\$ 2$ million, and a mission consisting primarily of giving limited financial support to Republican incumbents (Bonafede 1972). After 14 years of Vander Jagt's leadership, the NRCC had a budget of $\$ 34.5$ million and a staff of 80 full-time employees. In addition to participating with the RNC and the National Republican Senatorial Committee (NRSC) in candidate recruitment, producing partyfocused television campaign commercials, and financing voter mobilization drives, the NRCC also began furnishing House candidates with money and extensive campaign services (Adamany 1984; Price 1984). In 1988 , for example, the committee distributed $\$ 1.5$ million in cash and inkind contributions and over $\$ 4.1$ million in coordinated expenditures on behalf of its candidates (Federal Election Commission 1989). Virtually every incumbent and competitive nonincumbent Republican House candidate received the maximum legal contribution; the party also spent the maximum in coordinated expenditures on behalf of almost all of its competitive contestants (Hermson 1990). House candidates running in competitive districts also benefited from committee services in fundraising, polling, issue research, mass media advertising, and other campaign management functions requiring technical expertise, in-depth research, or connections with PACs, political consultants, or journalists (Hermson 1988 , 1989). The committee also built a media center capable of producing professional quality television and radio commercials and, until recently, sponsored a campaign management academy that has been credited with producing a pool of Republican political consultants.

Vander Jagt is largely responsible for transforming the NRCC from a weak, relatively insignificant party committee into one of the most formidable groups involved in congressional elections, and he has reaped considerable rewards for his party-building efforts. The tremendous increase in the status of the NRCC has been accompanied by a parallel increase in the status of the committee chairmanship and the person who occupies that office. As NRCC chair, Vander Jagt has advanced from being an unknown GOP backbencher to a major leader and spokesperson for his party. In 1980, he presented the keynote address at the Republican National Convention. By 1981, he had built a base of support large enough to come within 16 votes of being elected House Minority Leader. The closeness of the race was especially impressive because the person selected to be Minority Leader is almost always someone who has a proven record in the legislative process, which Vander Jagt lacked. 


\section{The Democratic Congressional Campaign Committee}

After years of internal factional struggles, the Democrats' first fullblown crisis of competition came in 1980 with the defeat of Jimmy Carter, loss of control of the Senate, and a loss of 34 House seats. Although Democratic House members suffered the least dramatic defeat, the Democratic Congressional Campaign Committee (DCCC) was the first Democratic organization to develop in response to the crisis.

During the 1970s, the DCCC employed four full-time staff members and operated out of the basement of the Rayburn House Office Building. Its primary activities consisted of raising money and distributing it to Democratic House members. Following the electoral crisis of 1980, Tony Coelho of California, first elected in 1978, sought the DCCC chair as a means to build an organization competitive with Vander Jagt's, and to improve his standing in the House as Vander Jagt had done. Speaker O'Neill, who was facing demands from his colleagues for increased campaign support, gave Coelho free reign over the organization. Coelho was active in the DCCC's day-to-day operations, running many of them in cooperation with his executive director Martin Franks. Their intention, according to Franks, was "to do the best damn job of copying the Republicans that [we] can" (Cohen 1986, 738). To achieve that goal, Coelho hired a professional staff and established the Speaker's Club, a large-donor program that the DCCC used to finance campaign contributions and organizational growth. He also invested more than $\$ 6$ million of the organization's 1981-1982 revenues into building a major direct-mail operation and a media center, and pushed strongly for a permanent joint headquarters for the three national Democratic organizations (Easterbrook 1986).

Coelho worked to establish the DCCC as a visible, combative voice supporting House Democrats and as an important source of contributions and services for their campaigns. Unlike many Democrats, Coelho and Franks publicly supported their party's candidates by directly attacking President Reagan. Perhaps the DCCC's most visible and immediate contribution was to articulate and hammer away at "the fairness issue," emphasizing the regressiveness of Republican economic policies. Following the Republican's successful example from 1980, the DCCC and the DNC ran television ads during the 1982 campaign arguing "It's Not Fair. It's Republican."

Under Coelho's leadership, the DCCC's income from direct-mail and large contributions grew from less than $\$ 3$ million in 1980 to more 
than $\$ 12$ million in 1986 . The committee's staff grew to 80 and began to provide an array of services similar to those provided by the NRCC, including polls, issue and opposition research, and television and radio campaign advertisements produced in the committee's media center. Similarly, committee spending in House races grew from about $\$ 650,000$ in 1980 to more than $\$ 2$ million in 1986 (FEC 1987). Coelho targeted party money and services to competitive House candidates, including nonincumbents, relying on Speaker O'Neill to fight off the objections of House members who were denied party assistance (Franks 1987).

By the end of the 1986 cycle, Coelho had established the DCCC as a major player in Democratic campaign politics. He also established himself as a major player in the House over the resistance of senior Democrats who did not receive contributions from the committee and the opposition of liberals who objected to his willingness to raise money from business PACs. Criticism faded when the Democrats picked up a net 26 seats in 1982 and lost only 14 in the 1984 Reagan landslide. Coelho was able to capitalize on the committee's success by having the DCCC chair elevated to a formal House Democratic leadership position in 1983. He raised his profile further in 1984, by presenting himself as the spokesperson for congressional "superdelegates" at the Democratic National Convention. Finally, after stepping down as DCCC chair in 1987, he managed the almost unprecedented feat of winning election as Majority Whip after serving only four terms in the House.

\section{The Democratic National Committee, 1980-1988}

Unlike the Nixon landslide of 1972, which many blamed on factional divisions within the party, Democrats immediately recognized the 1980 Reagan landslide to be a crisis of competition. Anne Campbell, former head of the Association of State Democratic Chairs, stated the problem bluntly: "The 1980 election was a referendum on national party structure. We were out-spent, out-targeted, and out-polled. The RNC did a superlative job. The Democratic Party should hang its head in shame" (Cook $1981,137)$. DNC members of all stripes agreed that rebuilding the DNC was needed and offered various proposals for change. Few advocated further rules reform or increased national party regulation. The two most common sets of proposals centered on the party's electoral competitiveness: some wanted to struggle to build a new party consensus on domestic and foreign policy issues; others wanted to follow the Republican example and pay more attention to the mechanics of winning elections. 
Like the textbook entrepreneur, Democratic National Finance Chair Charles Manatt stepped forward at the end of 1980 and presented himself as the only person who could effectively lead the DNC out of its doldrums. A former California state party chair and unsuccessful candidate for the national chair in 1972, Manatt ran for the top party post by offering DNC members a set of proposals for shifting organizational attention away from rules reform and towards making the party competitive. Adapting the Republican model to address the strengths and weaknesses of the Democratic Party, Manatt proposed new fundraising, especially from direct mail; development and delivery of campaign services to Democratic candidates and state and local party organizations; commissions and other forums to draw elected officials back into discussions of party governance and policy positions; and outreach to leaders of traditionally Democratic constituencies. In short, he proposed not only to expand the DNC's staff, but to dramatically reorient its division of labor and resources. The committee elected him unanimously in January of 1981 (Sweeney 1987).

Manatt moved quickly to establish a professional and financial base for the organization, recognizing that he had less than three years to make a mark before presidential politics would tie his hands. He first selected experienced political operatives from the party's several factions as his top officers, quickly rebuilding the staff to about 70 people. To pay for staff salaries and new party programs, Manatt stepped up large-donor appeals and borrowed $\$ 2.4$ million to cover start-up costs for a major direct-mail fundraising program. The direct-mail program was an eventual success, expanding from a 30,000 name list that financed 20 percent of the committee's expenses to a 500,000 -name list that raised more than $\$ 500,000$ a month, or 70 percent of the committee's costs (Kayden 1985).

Manatt's programmatic agenda for the DNC was less focused than his fundraising and staffing goals. Rather than start one initiative and develop it fully, he initiated a number of programs as quickly as possible, hoping that the appearance of organizational vitality would stimulate donations to support the vitality itself. Despite the dampening effect the 1980 landslide had on contributions in early 1981, Manatt started several campaign-oriented service programs for state and local party organizations and Democratic candidates early in the 1981-82 election cycle. He also helped found the Democratic National Training Academy in September 1981 , then rescheduled the party's midterm conference to July 1982 and converted it into a campaign kick-off event with candidate-training and issue workshops.

Manatt also established two sets of long-term initiatives. One set 
worked to shift the party's internal disputes away from the DNC. For example, a Democratic Strategy Council of national, state, and local officeholders was established to talk about policy issues, election strategies, and local events, thus shifting the burdens of issue politics back to party activists and candidates (Democratic National Committee 1984). Similarly, when confronted with the perennial problems of party rules and convention reform, Manatt appointed a new Commission on Presidential Selection headed by North Carolina Governor James Hunt, who agreed to work as quickly as possible to produce a consensus report.

Manatt's second set of long-term initiatives more closely followed the Republican campaign service-delivery model. The Democratic National Training Academy provided candidate and campaign manager training sessions to more than 5,000 Democrats around the country over a fouryear period. The DNC contributed over $\$ 250,000$ to congressional candidates in the 1982 and 1984 elections and invested even more money in a state and local party-building program. The committee also set up a voter mobilization program in support of the party's 1984 presidential ticket. Like William Brock, his Republican counterpart, Manatt worked to institutionalize services in very concrete ways. He convinced the DNC to join the DCCC in sponsoring the development of a multimillion dollar media center to provide television and radio facilities for Democratic candidates. Under his leadership, the DNC joined with the Democratic congressional and senatorial campaign committees to construct a $\$ 7$ million party headquarters building on Capitol Hill that was completed late in 1984 (Sweeney 1987).

After Reagan crushed Democratic nominee Walter Mondale in the 1984 election, Democratic leaders once again began to call for change at the DNC. Paul Kirk campaigned for DNC chair by promising Wisconsin and other state Democratic party leaders that he would relax delegate selection rules that had angered many Democratic activists and were believed to have hurt the party's ability to mobilize voters. Kirk also won Southern support, despite his ties to liberal Senator Edward Kennedy of Massachusetts, by promising to end the special status of narrow (often biological) caucuses within the structure of the DNC. After being elected DNC chair, Kirk implemented a refined version of Manatt's agenda. Like Manatt, Kirk continued to deal with the party's internal reform and policy disputes by directing them away from the national committee. In response to the charge in 1984 that the party was captive to special interest groups, Kirk eliminated offices representing several Democratic groups: blacks, hispanics, Asian-Americans, women, organized labor, and gays and lesbi- 
ans. He replaced the offices with regional field coordinators, arguing for concentration on elections rather than constituencies (Bonafede 1986). Kirk shifted reform and policy disputes to a short-lived Fairness Commission and a more elaborate Democratic Policy Commission. He invited party activists and elected officials from around the country to participate in working on a new party policy consensus (Democratic Policy Commission 1986).

Kirk also continued Manatt's focus on party competitiveness, although with a tighter focus and slightly different priorities. Kirk bolstered the committee's large-contributor program and made its direct-mail program an in-house operation, resulting in direct-mail fundraising becoming a stable source that financed 75 percent of DNC operations (Bonafede 1986). Kirk expanded the Democratic candidate training school, created an Office of Party Outreach to work directly with Democratic elected officials in state legislatures and local governments, dispatched four regional field coordinators and a team of national fieldworkers to work with candidates and Democratic party organizations in a total of 32 states during the 1986 and 1988 election cycles. The DNC also launched Project 500 , a program intended to win 500 more state legislative seats for Democrats in swing states before the 1992 reapportionment, and gave state party organizations access to the DNC's new computer facilities. Finally, the committee provided state parties with assistance in developing voter registration and direct-mail fundraising programs.

Manatt's and Kirk's entrepreneurial party-building activities enabled the DNC to develop an important presence both in Washington and around the nation. Although Manatt initiated many of the DNC's organizational transformations, he is not regularly credited with the committee's early successes or its continued development under Kirk. After leaving the DNC in 1985, Manatt briefly continued to play a role in Democratic politics, establishing a Washington-based consulting firm and joining Gary Hart's second bid to become the party's nominee for president. Kirk, on the other hand, played a brokering role in the Democrats' 1988 presidential nomination and turned over a well-established campaign organization with a bank account of \$6 million to Democratic nominee Michael Dukakis (Taylor 1989). Given the Democratic losses in the 1984 and 1988 presidential contests, the Democrats were unable to reward either Manatt or Kirk with a governmental appointment. Nonetheless, both chairmen played substantial roles in transforming the DNC into a modern campaign committee and an important party-building organization. 


\section{Delayed Organizational Response}

The same critical events that provided political entrepreneurs with opportunities to restructure the RNC and the NRCC after 1974, and the DCCC and the DNC after 1980, also created opportunities for organizational change at the two senatorial campaign committees. Nevertheless, these two committees did not experience change as quickly as did the other national party organizations. The delays in the development of the senatorial campaign committees can be attributed to the late arrival of political entrepreneurs and to the organizational politics of the committees themselves.

\section{The National Republican Senatorial Committee}

The Republicans emerged from the 1974 election holding only 38 Senate seats, and Republican Senate leaders expressed many of the same concerns voiced by other GOP leaders (Malbin 1974a). Although a window of opportunity for organizational change had opened at the NRSC, the committee's development was slower than that of the other two Republican national organizations. Between 1974 and 1976 the NRSC's budget barely reached $\$ 2$ million, while those of the Republican national and congressional campaign committees had climbed to just over $\$ 29$ million and \$12 million (Malbin and Skladony 1984). The NRSC's staff remained substantially smaller than the staffs of the other two organizations. The NRSC also was the last Republican national organization to occupy a party-owned headquarters building, moving into the Ronald Reagan Center after the 1988 election.

Post-crisis NRSC development was limited by a number of factors: a lack of continuity in committee leadership, the greater self-sufficiency of Senate candidates in comparison with candidates for other public offices, the comparatively smaller opportunity to create a vehicle with which to garner attention and credit in the Senate, and - perhaps consequently - the later arrival of a political entrepreneur. The chairmanship of the NRSC has rotated every two years since 1968 , allowing chairs limited time to accomplish their committee-oriented goals. Moreover, senators are fewer in numbers than House members, serve on a broader array of standing committees, and almost always represent much larger constituencies with a greater diversity of concerns. Calling attention to one's self in the capital or at home is not as great a problem for a senator. As a result, the NRSC's development has differed from that of the other two Republican national 
organizations in that the committee has not been upgraded into a fullblown campaign service center. It does not have a media center, nor does it get as deeply involved in the details of its candidates' campaigns as do the congressional campaign committees. According to Ceci Cole, NRSC communications director from 1980-1984, the major reason for the committee's different developmental path was leadership and staff recognition that Senate candidates are experienced campaigners who usually possess highly skilled campaign organizations (Cole 1985).

Because of their greater salience, and often greater prior campaign experience, Senate candidates do not need as much expert assistance from party staff. The problem for Senate candidates is raising enough money to wage competitive campaigns, rather than mastering the technologicallysophisticated techniques of modern campaigning. For that reason, according to Cole, NRSC chairs and staff have focused more on fundraising, spending strategies, and providing strategic advice than the delivery of campaign services.

In addition to these reasons, and no doubt partly because of them, the NRSC chair during the years immediately following Watergate (19751976) was not an ambitious party-builder. Senator Ted Stevens of Alaska had a wider avenue of interests and a more secure base of power than did the chairs of the other two committees. He devoted less energy to party organizational development and did not seek to use the NRSC chairmanship as a means for expanding his power within the Senate or the Republican Party.

Following Stevens' term, Robert Packwood of Oregon took over as NRSC chair. Packwood devoted substantial energy to winning and retaining the committee chairmanship. Like the other political entrepreneurs, he also undertook substantial efforts to strengthen it. In 1977, Packwood set up a direct-mail fundraising operation that collected contributions averaging $\$ 14$ each from 100,000 contributors (Cohen 1978). The fundraising operation helped to increase committee receipts from \$1.8 million in 1976 to $\$ 10.9$ million at the end of Packwood's first term in 1978 , and to $\$ 48.9$ million at the end of a second nonconsecutive term as chair in 1982 (Malbin and Skladony 1984). He expanded the NRSC's staff to over 30 full-time professional employees in 1982, making the committee an important source of money and campaign assistance for candidates. During the 1982 election cycle, the committee distributed over $\$ 550,000$ in contributions and $\$ 6.7$ million in coordinated expenditures. It provided candidates with substantial strategic advice and some campaign services.

Packwood's entrepreneurship, however, was not as well rewarded as 
that of Brock and Vander Jagt. His criticism in April 1982 of President Reagan's lack of concern for the needs of women, blacks, and other minority groups resulted in the White House ordering the NRSC to destroy $\$ 2$ million worth of fundraising letters bearing the President's signature and caused Packwood to fall into disfavor with his more conservative Senate colleagues (Congressional Quarterly 1983, 3-9). Shortly after the 1982 election, Packwood's bid to remain NRSC chair was defeated by by Richard Lugar of Indiana. In contrast to George McGovern, William Brock, and Guy Vander Jagt, Robert Packwood is an example of a failed entrepreneur, he invested time and energy into building the NRSC, but did not reap substantial rewards for his efforts.

Other recent NRSC chairs, including John Heinz of Pennsylvania (1979-1980, 1985-1986) and Richard Lugar (1983-1984), followed the party-building route taken by Packwood, expanding the committee's organizational apparatus and campaign activities. By 1986 the NRSC had become one of the foremost collectors and distributors of campaign money. In that year, its budget reached an unprecedented $\$ 86$ million and it spent over $\$ 9.5$ in Republican Senate races (FEC 1987). The NRSC's staff had grown to 90 full-time employees and a number of new election programs had been introduced. Perhaps the most heralded of these was the development of what NRSC executives refer to as the committee's "conduit role." Under the conduit role, NRSC officials request that committee supporters make contributions to competitive Republican candidates rather than to the committee itself. Occasionally, the committee collects these checks and delivers them to the candidates. This enables the committee to direct more campaign money to its competitive contestants than it can legally contribute to them or spend on their behalf (Herrnson 1988).

The NRSC provides an example of somewhat delayed and slightly limited party organizational development. The late arrival of a political entrepreneur forestalled committee development for two years, and the lack of continuous leadership slowed committee growth. NRSC development also differs from that of the other two Republican national organizations in that Packwood, Heinz, and Lugar can be thought of as unrewarded entrepreneurs. Packwood was unable to develop sufficient support either to oppose the President or to retain his job, Heinz failed in his 1981 bid for Republican Conference Chair (the third ranking position in the party leadership), and Lugar was defeated in his attempt to become Majority Leader after the 1984 election (Ehrenhalt 1985). The inability of these entrepreneurs to capitalize on their party-building activities links back to the limited duration of their tenures, which prevented an identification with 
party building commensurate to that of Brock and Vander Jagt, and to the greater salience and electoral self-sufficiency of senators, who seem to have felt less indebted to the NRSC and its chairs than Republican House candidates felt toward the NRCC and its chair.

\section{The Democratic Senatorial Campaign Committee}

Of all the Democratic defeats in 1980, the loss of the Senate majority was perhaps the most devastating. The Democrats had controlled the body since 1954 , at times by margins approaching two-to-one. When nine of their incumbents lost and the Republicans gained 12 seats, Senate Democratic leaders went into a panic. Despite this, the Democratic Senatorial Campaign Committee (DSCC) was the slowest of the three Democratic organizations to develop. This can be partially attributed to factors similar to those that retarded NRSC development: a tradition of rotating two-year chairmanships, the salience and self-sufficiency of Senate candidates, and the delayed arrival of a political entrepreneur.

Events shortly after the 1980 election stunted the DSCC's development for the remainder of the 1981-1982 election cycle. The only senator expressing interest in chairing the committee was Howard Metzenbaum of Ohio, a controversial liberal and no particular friend of conservative Majority Leader Robert Byrd. To avoid appointing Metzenbaum, Byrd asked Wendell Ford of Kentucky to continue chairing the committee for a third term. At the same time, Alan Cranston of California began working independently to set up the Democratic Leadership Circle (DLC) in order to replicate the Republicans' successful major-donor fundraising efforts. Although the DLC and the DSCC failed to fully mesh their efforts, the DLC helped to triple the DSCC's income from 1980 to 1982 . Yet, whereas Coelho invested more than half of the DCCC's income in direct mail and a new media center, Cranston and Ford simply passed their money on to Democratic Senate candidates, initiating only minimal organizational development.

It was not until Senator Lloyd Bentsen of Texas decided to take the DSCC chair in 1983 that the organization began to develop. Bentsen laid the groundwork for permanent organizational growth, following the lead of the DCCC, the DNC, and the competing Republican organizations. Although he only held the chair for two years, Bentsen merged the DLC and the DSCC and worked closely with DSCC executive staff to build a small, financially sound campaign-assistance center. According to Brian Atwood, the committee's executive director, and Audrey Sheppard, its 
political director, Bentsen worked personally to raise money from large donors, while DSCC staff developed a direct-mail program and an array of campaign programs ranging from candidate recruitment and training to intelligence gathering and strategic decision-making assistance. The committee also purchased polling services from Washington-based consulting firms and distributed them to Democratic candidates. The DSCC worked closely with about a dozen campaigns during the second Reagan landslide and, despite being outspent four-to-one by the NRSC in 1984, saw its candidates gain two seats in the Senate (Atwood 1987; Sheppard 1987).

At the end of the 1984 election cycle, the DSCC joined the other two national organizations in the new Democratic National Headquarters Building, and Byrd appointed George Mitchell of Maine to the chair. Mitchell, a long-time national party activist who had sought the DNC chair in 1972, built on Bentsen's initiatives in much the same way that Paul Kirk built on the work of Charles Manatt. Mitchell retained most of Bentsen's staff and continued to focus on expanding the committee's fundraising and campaign service programs.

Under Mitchell, the DSCC's financial base grew and the committee hired more professional staff and increased its campaign service programs. Because far more Republican than Democratic seats were up in 1986 (22 versus 12 ), Democratic strategists saw the election as an opportunity to win back control of the Senate and began the election cycle by expanding recruitment efforts (Taylor 1986). The committee worked closely with challengers throughout the cycle, providing them with strategic advice. More importantly, the DSCC was the single largest financial contributor to most of its challengers' campaigns.

For the first time since the early 1970 s, the DSCC raised more money than its House counterpart. Even in its relative wealth, however, the Senate committee pursued a distinct mission. While the DCCC assembled a professional staff of 80, the DSCC's staff never rose above 50 . The DSCC also continued to allocate far more of its budget directly to candidate contributions and coordinated expenditures on behalf of candidates than did its House counterpart.

Despite its growth and increased activity, 1986 was a very difficult year for Mitchell and the senatorial campaign committee. Control of the Senate was at stake and the large number of nonincumbent Democratic candidates placed severe demands on the DSCC's limited resources. Mitchell worked with the full complement of DSCC members in making allocation decisions, but controversy over the distribution of scarce resources threatened to undermine any credit he would receive for his party- 
building activities. ${ }^{5}$ Criticism faded after the election, however, when the Democrats won eight seats and regained control of the Senate. After the 1986 election, Mitchell's colleagues elected him Secretary of the Caucus, the third highest party leadership position in the Senate. Following the 1988 contest, Mitchell defeated Daniel Inouye of Hawaii and J. Bennett Johnston of Louisiana in the race for Senate Majority Leader.

The development of the DSCC has some important parallels to that of the NRSC. In both cases organizational change was stalled while nonentrepreneurs (Ford and Stevens) occupied the committee chairs. It was not until ambitious politicians who were willing to invest their energies into a party-building program were selected as committee chairs that either committee was launched on a course of institutional development. In addition, the DSCC and the NRSC have not developed campaign service programs that are as extensive as those of the House campaign committees. The Senate campaign committees differ from their House counterparts in that they distribute more money and advice than actual campaign services. Lastly, the entrepreneurs who worked to develop the DSCC and NRSC have not been rewarded as uniformly for their party-building activities as were the chairs of the national and congressional party organizations. Of the seven Democratic and Republican senatorial campaign committee chairs, only Mitchell was able to rise in the leadership ranks following his chairmanship, and his advancement may be attributed to his television skills and to the inherent political weaknesses of his opposition, as well as to his chairing the DSCC. Similarly, Bentsen's rise in prominence as his party's vice presidential nominee in 1988 had more to do with the geographical and ideological balance he brought to that ticket than with the party-building efforts he had undertaken as chair of the DSCC.

\section{Conclusion}

National party organizations have changed dramatically in the last 20 years. They have been transformed from poor, transitory, "powerless" committees to financially secure, stable, and highly influential political organizations. Contrary to political scientists' expectations only a decade ago, the national parties now play important roles in political campaigning, state and local party-building, and intraparty governance.

The transformation of the national party organizations was the result of a complex process that can only be fully understood by looking beyond the broad environmental forces that created the need for change. One must 
also focus on the internal politics of the organizations themselves and on the political needs and activities of those who sought to enhance the organizations' power and institutional development. Two conditions that are necessary for organizational transformation are a crisis that opens a window of opportunity for change and a political entrepreneur who takes advantage of it. The nature of the crisis, the goals of the entrepreneur, and the constraints imposed by the organization's constituency also contribute to the timing and the specific content of party organizational development.

The internal workings of party organizations and the activities of those who seek to change them help account for why organizational stagnation takes place when one might expect a party committee to adapt to environmental challenges. Contrary to functionalist expectations, party organizations often fail to reconcile factional disputes, respond to serious electoral competition, or adapt to broader systemic changes in the political system before these developments reach crisis proportions. Such problems began to arise for both Democrats and Republicans in the $1960 \mathrm{~s}$, but were not resolved until crises created the demand for change implemented by political entrepreneurs.

The internal dynamics of party organizations also help to explain the different paths of institutionalization taken by the six national party committees and help to account for the differences in their missions. The DNC and Democratic National Convention first turned to rules reform and intraparty regulation in order to resolve factional disputes that had been growing since the late 1940 s. The Republican national party organizations and their Democratic rivals developed state and local party-building and candidate-service programs in response to the crisis of competition that each faced after a major electoral defeat. The Republicans' greater success in the areas of party building and candidate-service provision can be attributed to the earlier occurrence of the GOP's crisis of competition, its earlier start in party building, its party leaders' success at keeping factional disputes out of its organizational politics, the more business-like style of Republican organizations, and the greater financial contributions of $\mathrm{Re}$ publican partisans. The sharp decline in voter support following Watergate encouraged GOP leaders to take action, while the secular decline in support for the Democratic Party went largely undetected and unaddressed by Democratic leaders. The Democrats' control of the House and Senate prior to 1980 also may have delayed that party's organizational development during the 1970 s.

Developmental differences among the national, congressional, and senatorial campaign committees also reflect the distinct challenges faced 
by each organization, differences in their internal politics, and the goals of the entrepreneurs who promoted organizational change. The NRCC and the DCCC developed into major centers of campaign assistance and services because political entrepreneurs such as Guy Vander Jagt and Tony Coelho sought to advance their House careers by tending to the electoral needs of their colleagues. The NRSC and DSCC developed more slowly, and focused more on the collection and distribution of campaign money than on the provision of campaign services, because more limited opportunities and rewards discouraged entrepreneurial leadership: twoyear rotating chairmanships, the greater availability of committee and constituency vehicles for attention, and the more modest campaign service needs of Senate candidates made it less likely that a senator could launch a bid for a leadership post solely on the basis of chairing a senatorial campaign committee.

Similarly, RNC and DNC development was influenced by the nature of the distinct crises these committees faced, the organizations' prior commitments, and political entrepreneurs' desires to balance the competing interests of party regulars and "amateur" activists. The Democratic Party's deeper ideological and policy factionalism provided George McGovern and other entrepreneurs with an opportunity to lead the DNC and the convention to rules reform and greater intraparty regulation. Only later, after the Democrats' dramatic loss in 1980, did the DNC begin to turn to the model of party building that the RNC pioneered in response to its own crisis of competition. It is doubtful that the Republicans will emulate the Democrats' movement towards a comprehensive body of national rules except under the unlikely circumstance that the GOP attracts so many new constituencies (e.g., minority groups) that Republican leaders must respond to the same kinds of factional pressures that have repeatedly strained relations among Democrats.

Party organizational development emerges from a complex process that can be fully understood by focusing on the nature of the problems that confront the parties, the crises that create opportunities for party organizational change, the motives and behaviors of the political entrepreneurs instigating the change, and the internal politics of the party organizations themselves.

\section{APPENDIX}

In addition to the sources cited in the text, information was collected through semi-structured and unstructured personal interviews with 60 officials at the Democratic 
and Republican national, congressional, and senatorial campaign committees. The interviews lasted between one-half hour and two hours, with the typical interview lasting slightly over one hour.

\section{NOTES}

${ }^{1}$ Entrepreneurial staff played an important, but less visible roles in the transformation of American national party organizations. Many staff were able to advance their careers as a result of their work at a party organization, albeit in less visible ways than party committee chairs. Some, like Tom King, formerly of the Democratic Congressional Campaign Committee, went on to establish their own successful political consulting firms. Others, like Mitch Daniels, formerly of the National Republican Senatorial Campaign Committee, received high ranking positions at the White House.

${ }^{2}$ The Hughes Commission recommended a similar set of reforms four years earlier, but few were implemented.

${ }^{3}$ The commission also mandated future midterm conferences, which were continued until Paul Kirk became DNC chair following the 1984 election.

${ }^{4}$ In 1964, Republican presidential nominee Barry Goldwater suffered a landslide defeat against President Lyndon Johnson, and the GOP lost 37 seats in the House and one seat in the Senate.

${ }^{5}$ Mitchell responded to the controversy by giving some of the DSCC's money to Senators and Senate candidates who helped the committee with its fundraising, instead of targeting committee resources solely to candidates competing in close elections.

\section{REFERENCES}

Adamany, David. 1984. "Political Parties in the 1980s." In Money and Politics in the United States, ed. Michael J. Malbin. Chatham, N.J.: Chatham House.

Atwood, Brian, executive director, Democratic Senatorial Campaign Committee. 1987. Interview in Washington, D.C. March 24.

Bibby, John F. 1979. "Political Parties and Federalism." Publius 9: 230-236.

Bibby, John F. 1981. "Party Renewal in the National Republican Party." In Party Renewal in America, ed. Gerald M. Pomper. New York: Praeger.

Bonafede, Dom. 1972. "White House Fund Raisers Enjoy Edge in GOP Scramble for Campaign Dollars." National Journal. September 30: 1522-1523

.Bonafede, Dom. 1986. “Kirk at the DNC's Helm." National Journal. March 22: 703707.

Cohen, Richard E. 1978. "Running Scared in Congress-The Parties Go Head-to-Head Over Money." National Journal. April 8: 557-561.

Cohen, Richard E. 1986. "The Best Offense.” National Journal. March 22: 738.

Cole, Ceci, communications director, National Republican Senatorial Committee. 1985. Interview held in Washington, D.C. January 4.

Commission on Party Structure and Delegate Selection. 1969. Mandate for Reform. Washington, D.C.: Democratic National Committee.

Congressional Quarterly. 1983. "98th Opens with Ceremonies, Partisan Fights." Congressional Quarterly Almanac: 3-9. 
Conway, M. Margaret. 1983. "Republican Political Party Nationalization, Campaign Activities, and their Implications for the Political System." Publius 13: 1-17.

Cook, Rhodes. 1981. "Chorus of Democratic Voices Urges New Policies, Methods." Congressional Quarterly Weekly Report. January 17: 137-140.

Cotter, Cornelius P. and John F. Bibby. 1980. "Institutional Development of the Parties and the Thesis of Party Decline." Political Science Quarterly 95: 1-27.

Cotter, Cornelius P. and Bernard C. Hennessy. 1964. Politics Without Power: The National Party Committees. New York: Atherton Press.

Cronin, Thomas E. 1975. The State of the Presidency. Boston: Little, Brown.

Democratic National Committee. n.d. The Charter and the Bylaws of the Democratic Party of the United States. Washington, D.C.: Democratic National Committee.

Democratic National Committee. 1984. Democratic National Committee, 1981-1985: Building for the Future. Washington, D.C.: Democrat National Committee.

Democratic Policy Commission. 1986. New Choices in a Changing America. Washington D.C.: Democratic National Committee.

Easterbrook, Glenn. 1986. "The Business of Politics." Atlantic Monthly. October: 28-38.

Ehrenhalt, Alan, ed. 1985. Politics in America. Washington, D.C.: Congressional Quarterly.

Eldersveld, Samuel. 1982. Political Parties in American Society. New York: Basic Books.

Epstein, Leon D. 1986. Political Parties in the American Mold. Madison, University of Wisconsin Press.

Federal Election Commission. 1987. FEC Press Release, May 31.

Federal Election Commission. 1989. FEC Press Release, March 27.

Franks, Martin, executive director, Democratic Congressional Campaign Committee. 1987. Interview in Washington, D.C. April 21.

Frantzich, Stephen E. 1989. Political Parties in the Technological Age. New York: Longman.

Glass, Andrew and Jonathan Cottin. 1971. "Democratic Reform Drive Falters as Spotlight Shifts to Presidential Race." National Journal. June 19: 1293-1304.

Goodwin, Richard. 1974. “A Divided Party.” New Yorker. December 7: 157-166.

Heclo, Hugh. 1974. Modern Social Politics in Britain and Sweden. Boston: Little, Brown.

Hermson, Paul S. 1988. Party Campaigning in the 1980s. Cambridge, Mass.: Harvard University Press.

Hermson, Paul S. 1989. "National Party Decision Making, Strategies, and Resource Distribution in Congressional Elections." Western Political Quarterly 42: 301-323.

Hermson, Paul S. 1990. "Reemergent National Party Organizations." In The Parties Respond, ed. L. Sandy Maisel. Boulder: Westview Press.

Kayden, Xandra. 1980. "The Nationalizing of the Party System." In Parties, Interest Groups, and Campaign Finance Laws, ed. Michael J. Malbin. Washington, DC: American Enterprise Institute, 257-282.

Kayden, Xandra. 1985. "The New Professionalism of the Oldest Party." Public Opinion. June/July: $42-44,49$.

Kayden, Xandra and Eddie Mahe, Jr. The Party Goes On (New York: Basic Books, 1985).

Kingdon, John W. 1984. Agendas, Alternatives, and Public Policies. Boston: Little, Brown. 
Light, Paul C. 1985. "Making the Most of the New Vice Presidency." In Analyzing the Presidency, ed. Robert E. DeClerico. Guilford, CN: Connecticut: Dushkin Publishing Group: 196-204.

Malbin, Michael J. 1974a. "Veto-Proof Congress Emerges as a Major 1974 Election Issue." National Journal. June 1: 809-816.

Malbin, Michael J. 1974b. "Controversy Over Charter Reflects Democratic Party Division." National Journal. September 21: 1407-1417.

Malbin, Michael J. 1975. "Republicans Prepare Plan to Rebuild Party for 1976." National Journal. March 1: 324-326.

Malbin, Michael J. 1977. "The Past and Future Parties." National Journal. February 5: 214.

Malbin, Michael J., and Thomas W. Skladony. 1984. "Appendix: Selected Campaign Finance Data, 1974-1982." In Money and Politics in the United States, ed. Michael J. Malbin. Chatham, N.J.: Chatham House.

National Journal. 1977. "Brock Picked to be RNC Chairman." January, 22: 150.

Price, David E. 1984. Bringing Back the Parties. Washington, D.C.: Congressional Quarterly.

Ranney, Austin. 1975. Curing the Mischiefs of Faction. Berkeley: University of California Press.

Sabato, Larry J. 1988. The Party's Just Begun. Glenview, Ill.: Scott Foresman/Little, Brown.

Salisbury, Robert H. 1969. “An Exchange Theory of Interest Groups.” Midwest Journal of Political Science: 13: 1-32.

Schlesinger, Joseph. 1985. "The New American Political Party." American Political Science Review 79: 1152-1169.

Shafer, Byron. 1983. The Quiet Revolution. New York: Russell Sage.

Sheppard, Audrey, political director, Democratic Senatorial Campaign Committee. 1987. Interview in Washington, D.C. September 29.

Sweeney, William, deputy chair, Democratic National Committee. 1987. Interview in Washington, D.C. August 13.

Taylor, Paul. 1986. "The Democrats Can Recapture the Senate-If Anybody Will Run." Washington Post National Weekly. January 20: 13-14.

Taylor, Paul. 1989. "Democrat's Chairman Faced Formidable Task." Washington Post. July 17.

Walters, Robert. 1974. "Democrats Adopt Charter Reforming Party Procedures." National Journal. December 14: 1891.

Wekkin, Gary D. 1984. "National-State Party Relations: The Democrats' New Federal Structure." Political Science Quarterly 99: 45-72.

Wekkin, Gary D. 1985. "Political Parties and Intergovernmental Relations in 1984: The Consequences of Party Renewal for Territorial Constituencies." Publius 15: 1937.

Wilson, James Q. 1973. Political Organizations. New York: Basic Books. 15: 19-37. 